\title{
ENACTMENT OF SUSTAINABLE TECHNOVATIONS ON HEALTHCARE SECTORS
}

\author{
Geetika Madaan', Swapna H.R2, Anuj Kumar³, Amrinder Singh4', Arokiaraj David5 \\ 1. University Centre for Research and Development, Chandigarh University, India \\ 2. Department of Commerce, Jain (Deemed to be University), India \\ 3. Apeejay School of Management, Dwarka, Delhi, India \\ 4.5. Department of Management Studies, Jain (Deemed to be University), India
}

Correspondence: anujsmooth@gmail.com

\begin{abstract}
This article discusses the use of innovative technologies and their potential to assist pan-India surveillance systems, including health initiatives. The key goal is to review prior studies on innovative technology and its use for existing healthcare sectors and identify association strength among the selected variables using Vos Viewer software.

Information gathered from research on randomized controlled trials, cross-sectional studies, review studies and systematic review studies, meta-analysis, sample, and case series. This article discusses the use of innovative technologies and their potential to assist pan-India surveillance systems, including health initiatives to community-based healthcare.
\end{abstract}

This paper discusses the current usage of Artificial Intelligence, Blockchain, and the Internet of Things (IoT) on health and developments.

The findings of the study state the complexities and opportunities of the mentioned technologies on the pan-India health surveillance system and indicates that data management, safety and security regulation gaps need to resolve before enforcing monitoring practices.

This paper presents an analysis of recent instances of using loT technologies centred on remote surveillance and indicate a need for an advanced computing architecture for future integrated with pilot and tracking operations.

\section{KEYWORDS}

Artificial intelligence; Blockchain; health sector; innovative technologies; Internet of things 


\section{INTRODUCTION}

Information management, networking technology and technical advances streamlined and improved health and environmental data collection. [1] For instance, the growing cloud storage computing power now currently allows the continuous collection of data via lightweight sensors. However, the information gathered has not always been properly used. Nevertheless, affordable data storage and the increasing technical computing capacity helps to build comprehensive health and environmental datasets of untapped potential. [2] [3]

Many investigations and research have recommended the idea of including emerging technology in the scope of climate change and the establishment of pan-Indian surveillance and monitoring practices linked to environmental protection and health system effects. [4] These practices may profit from a variety of emerging innovations, such as "Internet of Things," "cloud computing," "Artificial Intelligence," "Blockchain," "Machine Learning.", "Deep Learning." These groundbreaking innovations commonly utilized in many fields concerned with Comprehensive statistics including "influenza control and air quality monitoring" and demonstrate significant potential to facilitate the introduction of the pan-Indian surveillance mechanism. [5] [6] [7]

As our climate changes quickly and affects human health and welfare, the new health system needs necessitate adaptation and this paper tries to find the gap that is significantly correlated [8]. This paper discusses emerging attempts to address some of the problems using innovative technology. The study provides a review of prior literature and its implementation in the Indian health monitoring framework and a discussion of possible issues needed to incorporate the proposed Pan-Indian Monitoring System components. [9] The research aims to provide several descriptions of the present and potential implementations of these technologies in the healthcare sector.

\section{RESEARCH DESIGN}

The present study carried out using descriptive analysis, which practices a conventional literature review. Brainstorming session was performed during the talks to facilitate the usage scenarios concerning "Artificial Intelligence, Blockchain, and Internet of Things" cases. The researchers created a flowchart (mentioned in Figure 1) to show their procedures for selecting papers and to recommend the necessity of creative scope and creation of tracking and surveillance activities by combining the technologies and components of Artificial Intelligence, Blockchain, and Internet of Things. Although this was not a formal analysis of scoping, the present research adopted guidelines [10]. Since our goal is to be more precise. In this methodological context, six steps for the systematic review are suggested (as mentioned in table 1). 


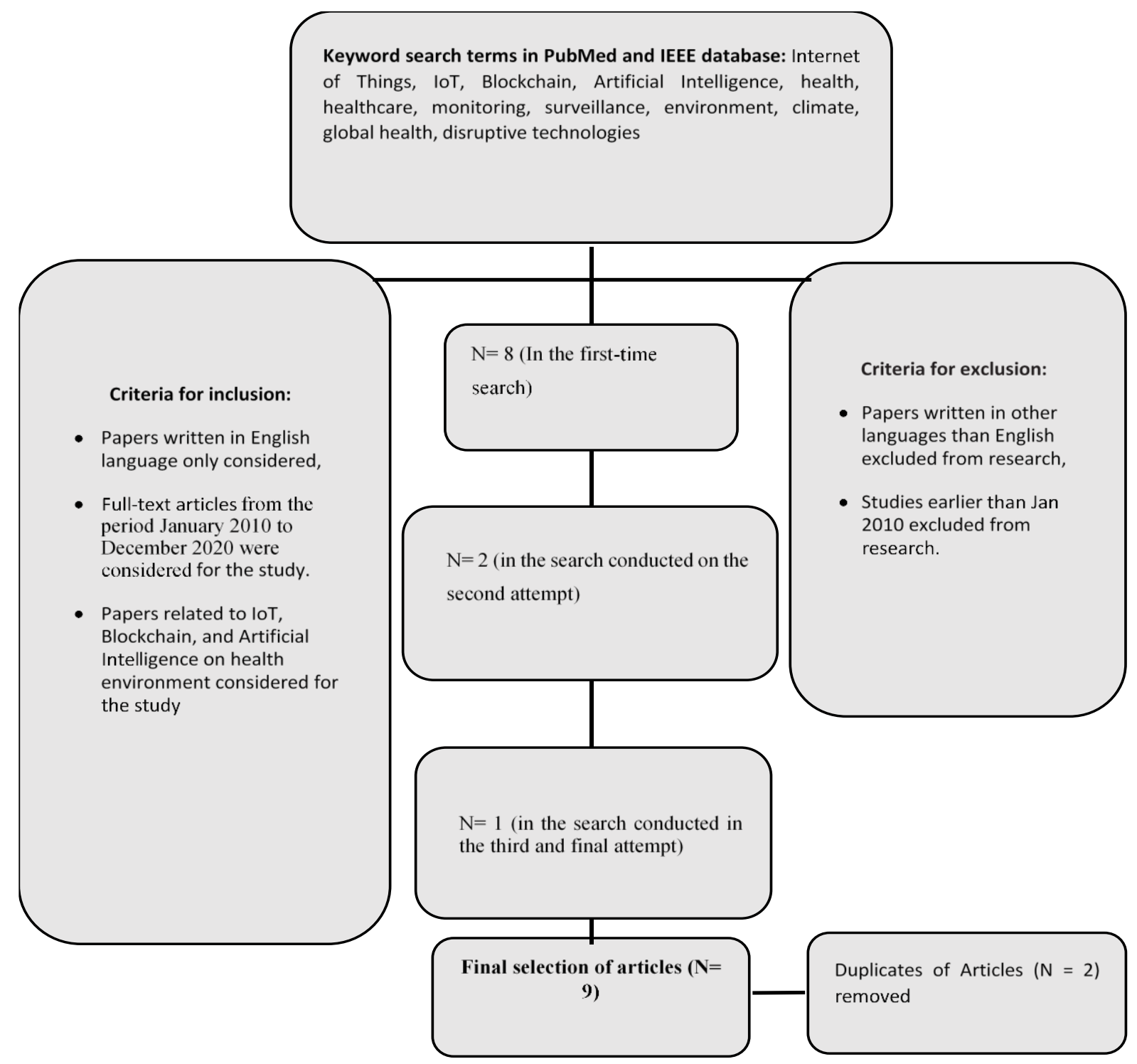

\section{RESEARCH METHODS}

\begin{tabular}{|l|l|}
\hline Research Question & $\begin{array}{l}\text { In this study, we aimed at explaining "How disruptive technology based on Artificial } \\
\text { Intelligence, Blockchain, and Internet of Things will help boost environmental and } \\
\text { health research? " }\end{array}$ \\
\hline Articles searching & Articles extracted from Scholarly databases, namely, PubMed and IEEE. \\
\hline Study design & $\begin{array}{l}\text { Information gathered from research on randomized controlled trials, cross-sectional } \\
\text { studies, review studies and systematic review studies, meta-analysis, sample, and } \\
\text { case series. }\end{array}$ \\
\hline Sources of Data collection & $\begin{array}{l}\text { The data collection process carried out by studying previous research carried out at } \\
\text { different levels concerning the usage of multiple disruptive technologies in health } \\
\text { and the climate. }\end{array}$ \\
\hline Variables Assessed & $\begin{array}{l}\text { Several classes of indicators are gathered after a final literature analysis of the } \\
\text { articles. Factor includes: "Internet of Things", "IOT", "Blockchain", "Artificial } \\
\text { Intelligence", "Health", "Healthcare", "monitoring", "surveillance", "environment", } \\
\text { "climate", "health". }\end{array}$ \\
\hline The compilation, Results, and \\
monitoring
\end{tabular}


The intensive review of many academic papers and government studies on innovations, including "Internet of Things, Blockchain, and Artificial Intelligence", can create the tremendous potential to promote health and environmental information [11]. The present study attempted to determine the association strength among the variables studied by the researchers of the selected articles through the Vos Viewer software version 1.6.15. First, the mapping is done for the most occurred keywords used by the various researchers in different articles (Figure 2) and a broader view of network visualization of most occurred keywords in the selected articles also showed in figure 3. Then the formation of clustering was identified through the mapping of most occurred keywords present in the prior studies. The formation of clustering depicted the presence of 3 clusters-the description of the formed cluster through Vos viewer mentioned in table 2.

\section{FIGURE 2- MAPPING OF MOST OCCURRED KEYWORDS IN THE SELECTED ARTICLES}

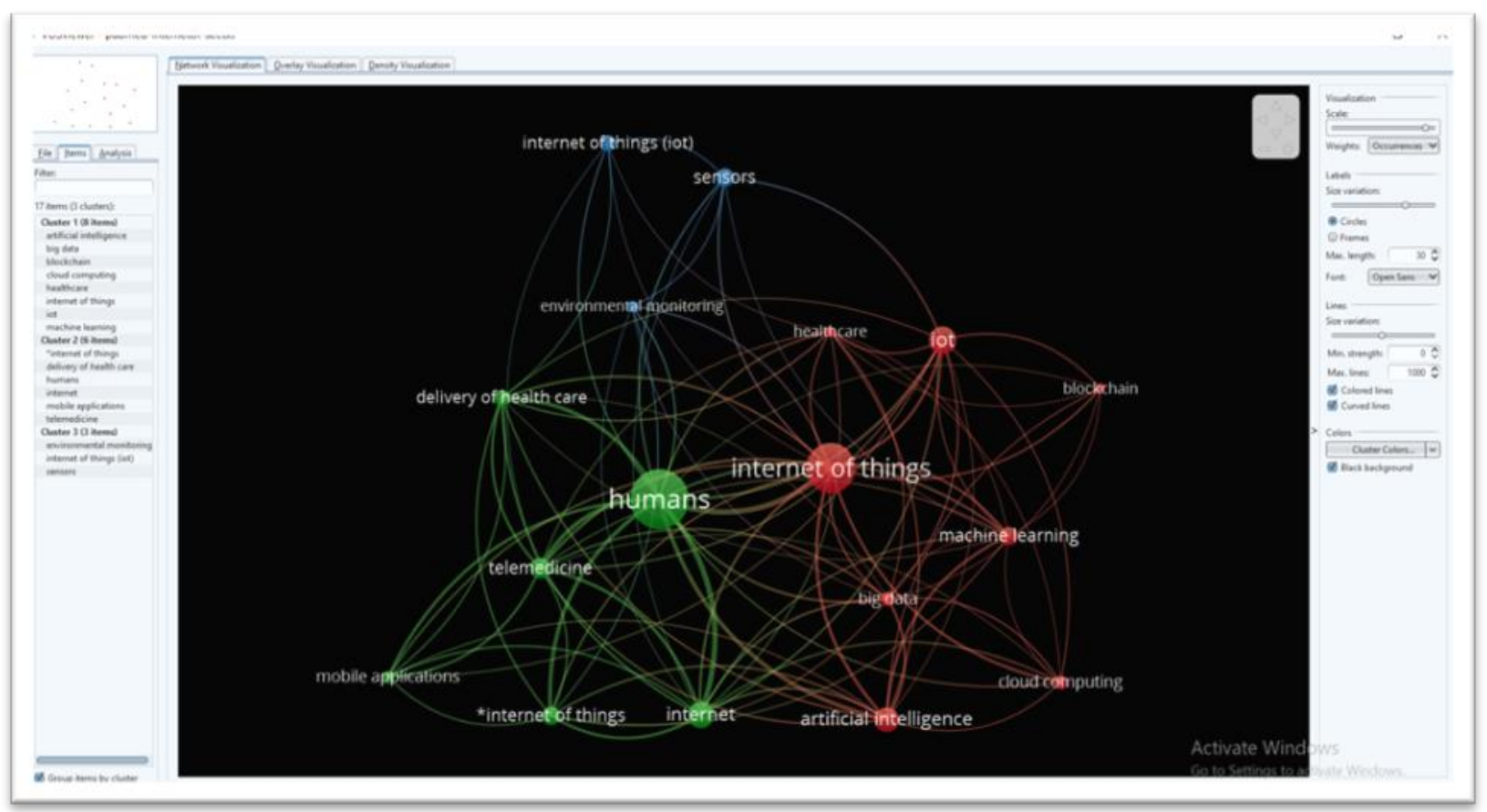

FIGURE 3- NETWORK VISUALIZATION OF MAPPING OF MOST OCCURRED KEYWORDS IN THE SELECTED ARTICLES

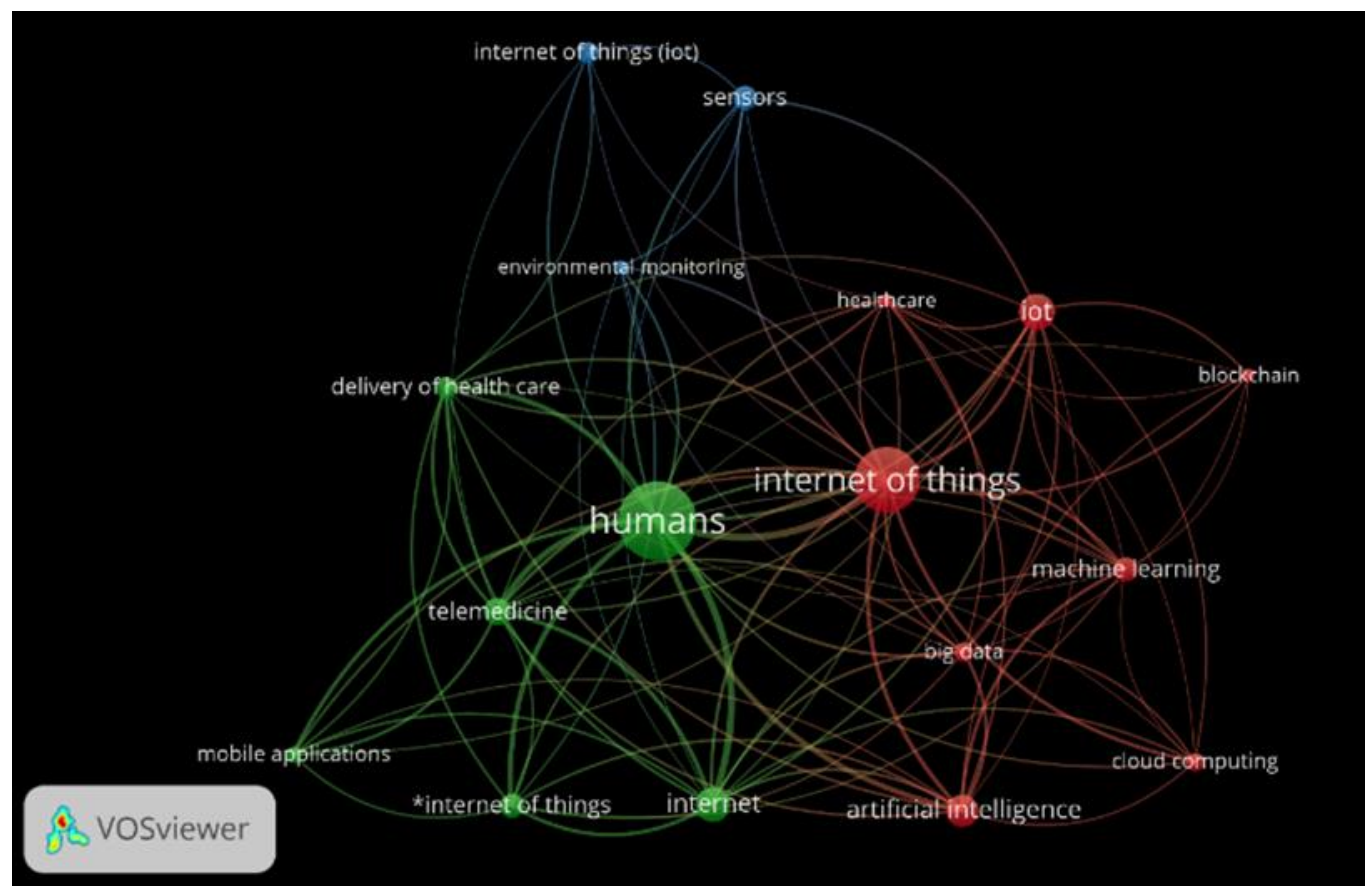


TABLE 2- DESCRIPTION OF CLUSTERS FORMED THROUGH VOS VIEWER SOFTWARE

\begin{tabular}{|l|l|l|}
\hline S.NO. & NUMBER OF CLUSTERS & DESCRIPTION OF CLUSTER \\
\hline $\mathbf{1 .}$ & Cluster $\mathbf{1}$ (8 items) & Artificial Intelligence \\
& & Big data \\
& & Blockchain \\
& & Cloud computing \\
& & Healthcare \\
& & Internet of things \\
& & loT \\
& & Machine learning \\
\hline & \multicolumn{2}{|l|}{} \\
\hline $\mathbf{2 .}$ & Cluster 2 (6 items) & Internet of things \\
& & Delivery of healthcare \\
& & Humans \\
& & Internet \\
& & Mobile applications \\
& & Telemedicine \\
\hline
\end{tabular}

FIGURE 4- NETWORK VISUALIZATION OF MAPPING OF MOST INFLUENTIAL KEYWORDS

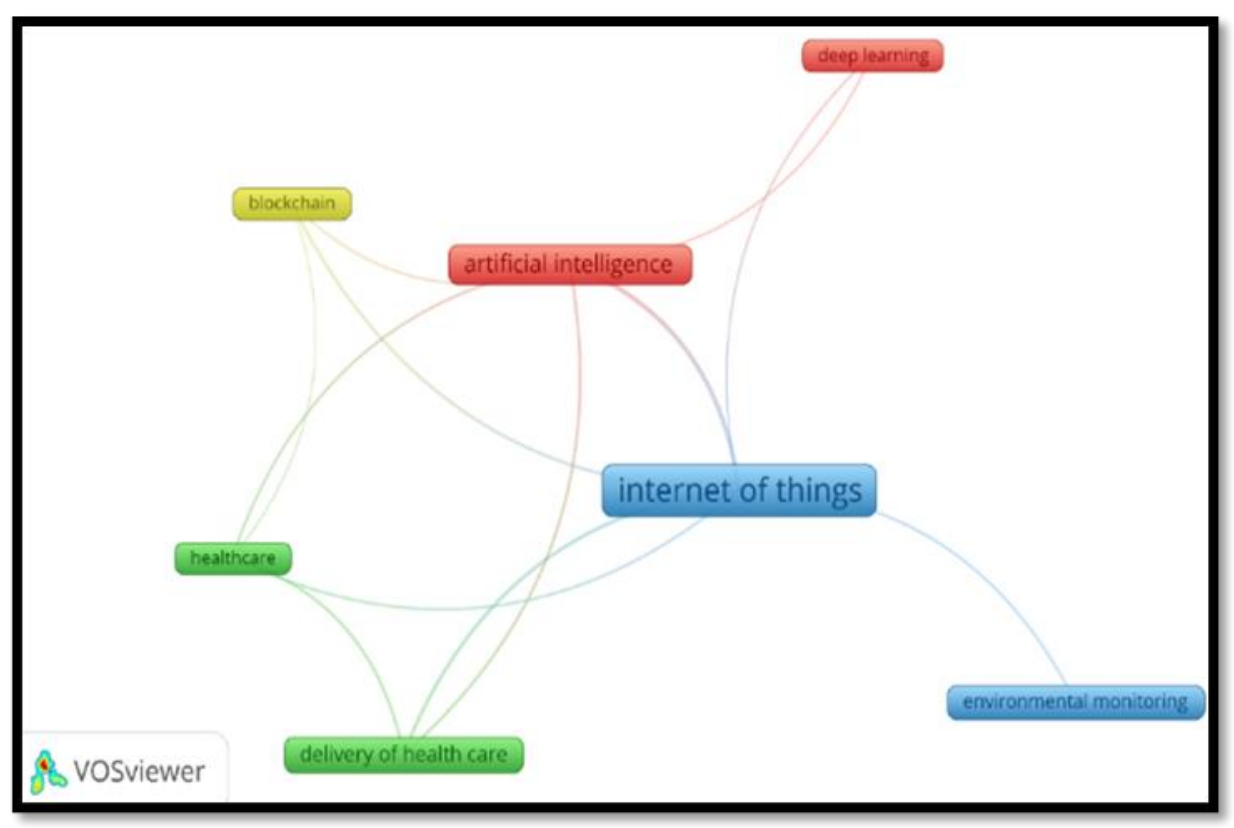

After forming clusters from most occurred keywords, the study further identified the presence of mapping of most influential keywords formed in Vos Viewer software (figure 4).

The network visualization depicted association strength among the most influential keywords extracted from the selected articles. Keywords, namely, "artificial intelligence," "deep learning," "internet of things," "blockchain," "environmental monitoring," and "healthcare," and "delivery of health care," showed strong association strength and indicated the relationship among the most influential keywords. 
The study made a comprehensive analysis of each innovative technology and assessed their enactment in the health and environment domain as discussed below:

\section{INTERNET OF THINGS}

The loT is an evolving heterogeneous idea of networking that aims to influence the modern environment today significantly. loT's central vision is to combine a vast range of intelligent artifacts towards interconnected and interconnecting networks, rendering the Internet much more all-embracing. [12] [13] It is a modern model in which every system communicates in a seamless world, irrespective of its scale, calculation capital, and network connectivity.

\subsection{Internet of Things in Health}

The World Health Organization describes surveillance in public protection as "the ongoing compilation, systematic review and assessment of health-related data required for the preparation, execution, and assessment of public health procedure." [14] Monitoring is critical when developing and enforcing public health agencies' preventive and control measures. [15] [16]

Public health monitoring has some ongoing issues that must overcome. These challenges may be technological or nontechnical in conjunction with data usage and access. [17] The shortage of technology, competent human capital, and sufficient finance are the key obstacles to public health monitoring. Non-technical problems cover ethics, safety, and protection considerations, but it is deemed essential to gain informed consent to the implementation of healthcare research. [18]

\section{BLOCKCHAIN}

\subsection{Blockchain in Healthcare}

Healthcare is a diverse industry comprising various players, including patients, physicians, hospitals/clinics, researchers, insurance providers, and pharmaceutical firms. The sector is progressively digital, creating prospects for development in precision medicine, improved health systems, and quality treatment.

Since providers are the main data administrators and their networks are prone to data exchange and interoperability problems with other providers, patients lose their prior clinical history and therefore hinder a comprehensive health perception.

\section{ARTIFICIAL INTELLIGENCE}

\subsection{Artificial Intelligence in Health}

Both the central and state governments are critical in environmental and public health monitoring. Central and state governments, especially environmental regulators, face problems. For example, the limitations on financial and human capital, which may restrict the extent of surveillance activities. The use of technologies, namely, Big Data Analytics, Artificial Intelligence, Internet of Things, Machine Learning can assist in prompt and effective execution of vital activities, such as the management of water contaminants to preserve water ecosystems and drinking water safety. [19] [20] [21]

TABLE 3- COMPREHENSIVE REVIEW OF ARTICLES RELEVANT TO THE CURRENT STUDY

\begin{tabular}{|c|c|c|c|c|c|}
\hline $\begin{array}{l}\text { TECHNOLO } \\
\text { GY }\end{array}$ & $\begin{array}{l}\text { STUDY } \\
\text { AREA }\end{array}$ & $\begin{array}{l}\text { RESEARCH } \\
\text { OBJECTIVE }\end{array}$ & CHALLENGES & OPPORTUNITIES & $\begin{array}{l}\text { REFERE } \\
\text { NCE }\end{array}$ \\
\hline $\begin{array}{l}\text { Internet of } \\
\text { Things }\end{array}$ & Health & $\begin{array}{l}\text { A review of the } \\
\text { current research, } \\
\text { regulatory, technical, } \\
\text { and analytical } \\
\text { landscape was the } \\
\text { objective of this study } \\
\text { in the field of } \\
\text { oncology research } \\
\text { and treatment for } \\
\text { patients provided } \\
\text { health data (PGHD). }\end{array}$ & $\begin{array}{l}\text { Electronic integration of } \\
\text { patient reporting results } \\
\text { and biometrical } \\
\text { evidence, review of } \\
\text { broad and diverse } \\
\text { biometric data sets, } \\
\text { and future clinical } \\
\text { process overhaul would } \\
\text { be among the } \\
\text { challenges. }\end{array}$ & $\begin{array}{l}\text { Within the framework } \\
\text { of big data and } \\
\text { artificial intelligence in } \\
\text { medicine, } \\
\text { computational } \\
\text { possibilities for patient- } \\
\text { generated health data } \\
\text { are envisaged }\end{array}$ & [22] \\
\hline
\end{tabular}




\begin{tabular}{|c|c|c|c|c|c|}
\hline $\begin{array}{l}\text { Internet of } \\
\text { Things }\end{array}$ & Health & $\begin{array}{l}\text { Identifying and } \\
\text { mapping the latest } \\
\text { IOT advances in } \\
\text { medicine and } \\
\text { functional loT in } \\
\text { medicine, the active } \\
\text { medical regions, and } \\
\text { IOT places. }\end{array}$ & $\begin{array}{l}\text { The healthcare sector is } \\
\text { a vast and dynamic } \\
\text { entity of active } \\
\text { participation by } \\
\text { multiple stakeholders, } \\
\text { including patients, } \\
\text { health care } \\
\text { professionals, and } \\
\text { insurance agencies. } \\
\text { However, loT currently } \\
\text { does not engage in } \\
\text { specific medical fields. }\end{array}$ & $\begin{array}{l}\text { IOT apps usually built to } \\
\text { save money and allow } \\
\text { patients to be inspired } \\
\text { at home. This } \\
\text { eventually leads to } \\
\text { wellness promotion } \\
\text { and increased human } \\
\text { well-being. }\end{array}$ & [23] \\
\hline Blockchain & Health & $\begin{array}{l}\text { To assess the } \\
\text { blockchain adoption } \\
\text { within the food supply } \\
\text { chain, thus ensuring } \\
\text { the wellness of } \\
\text { human beings. }\end{array}$ & $\begin{array}{l}\text { Five future obstacles, } \\
\text { including a lack of } \\
\text { better understanding of } \\
\text { blockchain, } \\
\text { infrastructure } \\
\text { challenges, raw data } \\
\text { management, } \\
\text { problems are bringing } \\
\text { all stakeholders into it, } \\
\text { and regulatory } \\
\text { limitations. }\end{array}$ & $\begin{array}{l}\text { The Internet of Things } \\
\text { (IOT) may be utilised to } \\
\text { enhance food } \\
\text { traceability, } \\
\text { transparency of } \\
\text { knowledge, and } \\
\text { recovery quality } \\
\text { through Blockchain. }\end{array}$ & [24] \\
\hline $\begin{array}{l}\text { Artificial } \\
\text { Intelligence }\end{array}$ & Health & $\begin{array}{l}\text { Artificial intelligence's } \\
\text { role in the research } \\
\text { and preparedness of } \\
\text { COVID-19 } \\
\text { (Coronavirus) } \\
\text { prevention and } \\
\text { combat is critical. }\end{array}$ & $\begin{array}{l}\text { Medical organizations } \\
\text { desperately require } \\
\text { artificial intelligence } \\
\text { systems to treat } \\
\text { coronaviruses and allow } \\
\text { them to receive } \\
\text { accurate suggestions in } \\
\text { real-time to prevent } \\
\text { their spread. }\end{array}$ & $\begin{array}{l}\text { Artificial intelligence } \\
\text { works conveniently for } \\
\text { the emulation of } \\
\text { intellect shown by } \\
\text { humans. Additionally, it } \\
\text { may be important in } \\
\text { understanding and } \\
\text { creating a COVID-19 } \\
\text { vaccine. }\end{array}$ & {$[25]$} \\
\hline $\begin{array}{l}\text { Artificial } \\
\text { Intelligence }\end{array}$ & Health & $\begin{array}{l}\text { To investigate artificial } \\
\text { intelligence as an } \\
\text { advancement in } \\
\text { digital healthcare } \\
\text { and point out future } \\
\text { risks and } \\
\text { opportunities. }\end{array}$ & $\begin{array}{l}\text { Technologies in artificial } \\
\text { intelligence and } \\
\text { different threats } \\
\text { involved with their } \\
\text { application. It is } \\
\text { necessary to } \\
\text { understand this before } \\
\text { implementing } \\
\text { technologies, given the } \\
\text { path dependence } \\
\text { usually seen in } \\
\text { innovation diffusion } \\
\text { patterns. }\end{array}$ & $\begin{array}{l}\text { Artificial intelligence } \\
\text { can transform } \\
\text { healthcare by } \\
\text { improving clinical } \\
\text { procedures and } \\
\text { enhancing workflows. } \\
\text { Artificial Intelligence } \\
\text { has three main } \\
\text { attributes as an } \\
\text { innovation: "it is self- } \\
\text { referential, } \\
\text { programmable and } \\
\text { able to achieve } \\
\text { marked generativity." }\end{array}$ & [26] \\
\hline
\end{tabular}




\section{DISCUSSION}

Many of the literature have studied echoed comments about the need for clarity before a data-sharing infrastructure is effectively implemented since uncertainty in managing private data creates a loss of faith. Several problems for the enactment of health monitoring technologies have appeared in previous studies by different researchers. The fundamental problems were interoperability, data exchange and data administration, and safety, confidence, and protection.

As data gathered from several outlets, various parties need to be interested in developing data sharing policies. This heterogeneity renders data possession and data processing impossible to evaluate.

In health applications, loT devices' usage impacts privacy even further since the sharing of sensitive details in these technologies is not yet precisely controlled. Problems such as equity often create concern that only mid- to highincome citizens profit from adopting a scheme using highend loT tools to boost regular lives. This problem is related closely to the need for improved responsibility including consistency of data ownership and administration.

\section{CONCLUSION}

To scope and improve reporting and monitoring programs on environmental effects on health and health networks, the present study recommends multidisciplinary partners, including government, public researchers, different sectors, suppliers of services, or innovators. The current study indicates that data management, safety, and security regulation gaps need to resolve before effective monitoring practices enforced. The public, particularly young people more aware and easily adapt to technical and technological régime. However, There's always an issue of trust and a need for digital literacy education and growth.

Although innovations including "IoT", "Blockchain", and "Artificial Intelligence" have enormous potential to encourage convergence of health and environmental data, still, disadvantages and complexities remain in using these technologies in health monitoring, which should tackle as a priority. The concentrated attempts to review various academic papers and government reports and the recommendations for control and operations by the technical infrastructure provide interesting details for potential research.

\section{References}

1. Dash S, Shakyawar SK, Sharma M, Kaushik S. Big data in healthcare: management, analysis and future prospects. J Big Data [Internet]. 2019;6(1). Available from: https://doi.org/10.1 186/s40537-019-0217-0

2. Bibri SE. On the sustainability of smart and smarter cities in the era of big data: an interdisciplinary and transdisciplinary literature review. J Big Data [Internet]. 2019;6(1). Available from: https://doi.org/10.1186/s40537-019-0182-7

3. Khan N, Yaqoob, Hashem, Inayat, Ali, Alam, et al. Infrared Spectroscopy of Metal-MgO Single Crystalline Composite Films. Jpn J Appl Phys. 2014;29(8):2-17.

4. Frumkin $\mathrm{H}$, Hess J, Luber G, Malilay J, McGeehin M. Climate change: The public health response. Am J Public Health. 2008;98(3):435-45.

5. Saini J, Dutta M, Marques $G$. Indoor air quality monitoring systems based on internet of things: A systematic review. Int J Environ Res Public Health. 2020;17(14):1-22.

6. Lee D, Kang S, Shin J. Using deep learning techniques to forecast environmental consumption level. Sustain. 2017:9(10):1-17.

7. Rodrigues JJPC, De Rezende Segundo DB, Junqueira HA, Sabino MH, Prince RMl, Al-Muhtadi J, et al. Enabling Technologies for the Internet of Health Things. IEEE Access. 2018;6(January):13129-41.

8. Butler CD. Climate change, health and existential risks to civilization: A comprehensive review (1989-2013). Int J Environ Res Public Health. 2018;15(10).

9. Lee LM. Public Health Data Collection and Implementation of the Revised Common Rule. J Law, Med Ethics. 2019;47(2):232-7.

10. Levac D, Colquhoun H, O'Brien KK. Scoping Studies: Advancing the Methodology. Implement Sci. 2010;5(1):2-9

11. Reyna A, Martín C, Chen J, Soler E, Díaz M. On blockchain and its integration with loT. Challenges and opportunities. Futur Gener Comput Syst. 2018;88(2018):173-90. 
12. Gomez-Marquez J, Hamad-Schifferli K. Distributed Biological Foundries for Global Health. Adv Healthc Mater. 2019;8(18):1-19.

13. Jo D, Kim GJ. AR enabled loT for a smart and interactive environment: A survey and future directions. Sensors (Switzerland). 2019;19(19).

14. Manisalidis I, Stavropoulou E, Stavropoulos A, Bezirtzoglou E. Environmental and Health Impacts of Air Pollution: A Review. Front Public Heal. 2020;8(February):1-13.

15. Domb M. Wearable Devices and their Implementation in Various Domains. Wearable Devices - Big Wave Innov. 2019;5(2):1-20.

16. Summers JK, Smith LM, Fulford RS, Crespo R de J. The Role of Ecosystem Services in Community Well-Being. Ecosyst Serv Glob Ecol. 2018;

17. Sivarajah U, Kamal MM, Irani Z, Weerakkody V. Critical analysis of Big Data challenges and analytical methods. J Bus Res [Internet]. 2017;70:263-86. Available from: http://dx.doi.org/10.1016/j.jbusres.2016.08.001

18. Sima V, Gheorghe IG, Subić J, Nancu D. Influences of the industry 4.0 revolution on the human capital development and consumer behavior: A systematic review. Sustain. 2020;12(10).

19. Ahmed Z, Mohamed K, Zeeshan S, Dong XQ. Artificial intelligence with multi-functional machine learning platform development for better healthcare and precision medicine. Database (Oxford). 2020;2020:135.
20. Kumar GS, Kar SS, Jain A. Health and environmental sanitation in India: Issues for prioritizing control strategies. Indian J Occup Environ Med. 2011;15(3):936.

21. McGovern A, Elmore KL, Gagne DJ, Haupt SE, Karstens $C D$, Lagerquist $R$, et al. Using artificial intelligence to improve real-time decision-making for high-impact weather. Bull Am Meteorol Soc. 2017;98(10):2073-90.

22. Jim HSL, Hoogland Al, Brownstein NC, Barata A, Dicker $A P, K n o o p ~ H$, et al. Innovations in research and clinical care using patient-generated health data. CA Cancer J Clin. 2020;70(3):182-99.

23. Sadoughi F, Behmanesh A, Sayfouri N. Internet of things in medicine: A systematic mapping study. J Biomed Inform [Internet]. 2020;103(January):103383. Available from: https://doi.org/10.1016/j.jbi.2020.103383

24. Duan J, Zhang C, Gong Y, Brown S, Li Z. A contentanalysis based literature review in blockchain adoption within food supply chain. Int J Environ Res Public Health. 2020;17(5).

25. Vaishya R, Javaid M, Haleem I, Haleem A. Diabetes \& Metabolic Syndrome : Clinical Research \& Reviews Arti fi cial Intelligence ( Al) applications for COVID-19 pandemic. Diabetes Metab Syndr Clin Res Rev. 2020; 14:337-9.

26. Arora A. Conceptualising artificial intelligence as a digital healthcare innovation: An introductory review. Med Devices Evid Res. 2020;13:223-30. 